\title{
Aplikasi Bawang Merah dan Bawang Putih Memperlambat Pembentukan Bintik Hitam pada Udang Vaname
}

\author{
[Application of Onions and Garlic Slows the Formation of Black Spots on \\ Whiteleg Shrimp]
}

\author{
Tatty Yuniarti ${ }^{1}$, lin Siti Djunaidah ${ }^{1}$, Lilis Supenti ${ }^{1}$, Suharyadi ${ }^{2}$ \\ 1)Sekolah Tinggi Perikanan, Jurusan Penyuluhan Perikanan \\ Jalan Cikaret Nomor 2 Bogor 16001, Jawa Barat \\ 2)Sekolah Tinggi Perikanan JI. AUP Pasar Minggu, Jakarta Selatan
}

Diterima: 5 Mei 2018; Disetujui: 25 Juli 2018

\begin{abstract}
Abstrak
Bawang mengandung senyawa bioaktif, seperti organosulfur, komponen fenolik, dan flavonoid yang mempunyai kemampuan antioksidan. Udang pada saat keluar dari air, mengalami reaksi oksidasi enzimatik, asam amino tirosin yang mengandung gugus fenol dioksidasi oleh enzim polifenol oksidase, mengakibatkan pembentukan bintik hitam atau blackspot pada tubuh udang. Pembentukan blackspot tersebut dapat menurunkan nilai ekonomi, sehingga merugikan perusahaan udang segar. Penelitian bertujuan meneliti bawang merah (Allium cepa L.) dan bawang putih (Allium sativum) yang diekstraksi menggunakan air terhadap pembentukan blackspot pada udang vaname (Litopeneaus vannameii). Udang direndam menggunakan larutan ekstrak bawang merah dan bawang putih (1:1 dan 1:2), disimpan selama 10 hari pada suhu $0{ }^{\circ} \mathrm{C}$. Udang tanpa ekstrak bawang dan udang dengan sodium metabisulfit (SMS) digunakan sebagai kontrol negatif dan kontrol positif. Nilai melanosis udang dengan perendaman ekstrak bawang merah perbandingan 1:1 pada penyimpanan hari ke-10, lebih rendah dibandingkan dengan ekstrak bawang lainnya, sehingga memperlambat pembentukan blackspot namun masih lebih efektif bila menggunakan SMS. Pengaruh ekstrak bawang terhadap kesegaran udang diamati pada atribut kenampakan, secara umum mengalami kemunduran mutu paling cepat dibandingkan atribut bau dan tekstur. Penambahan ekstrak bawang merah dan bawang putih tidak menimbulkan perubahan mutu atribut tekstur dan bau yang siginifikan dibandingkan dengan kontrol. Nilai indeks browning menunjukkan udang dengan perendaman bawang merah 1:1 mengalami perubahan yang paling lambat dibandingkan lainnya. Ekstrak air bawang merah : akuades dengan perbandingan 1:1 berpotensi digunakan sebagai bahan penghambat pembentukan blackspot udang vaname, tanpa memberikan pengaruh terhadap bau dan tekstur udang.
\end{abstract}

Kata kunci: bawang; blackspot; browning; melanosis; udang vaname

\section{Abstract}

Onions contain bioactive compounds, such as organosulfur, phenolic components, and flavonoids that have antioxidant abilities. Shrimp when out of water, undergo enzymatic oxidation reactions, tyrosine amino acids containing phenol groups are oxidized by the enzyme polyphenol oxidase, resulting in the formation of blackspots in the body of the shrimp. The formation of these blackspots can reduce economic value, thus harming the company of fresh shrimp. The study aimed to examine onions (Allium cepa L.) and garlic (Allium sativum) extracted using water on the formation of blackspots in whiteleg shrimp (Litopeneaus vannameii). Shrimp soaked using a solution of onion and garlic extract (1:1 and 1:2), then stored for 10 days at $0^{\circ} \mathrm{C}$. Shrimp without onion extract and shrimp with sodium metabisulfite (SMS) were used as negative controls and positive controls. The value of melanosis of shrimp with soaking red onion extract is a ratio of $1: 1$ at $10^{\text {th }}$ day storage, lower than other onion extracts, thus slowing the formation of blackspots but still more effective when using SMS. The effect of onion extract on shrimp freshness was observed in appearance attributes, generally experiencing the fastest deterioration in 
quality compared to attributes of smell and texture. The addition of onion and garlic extract did not cause a significant change in the quality of the texture and odor attributes compared to the controls. Browning index value shows shrimp with 1: 1 soaking onion experiencing the slowest change compared to the others. Red onion water extract: distilled water with a ratio of 1:1 has the potential to be used as an inhibitor for the formation of whiteleg blackspot, without giving effect to the smell and texture of shrimp.

Keywords: blackspot; browning; melanosys; onion; whiteleg shrimp

\section{Penulis korespondensi}

Tatty Yuniarti | tatty.yuni@gmail.com

\section{PENDAHULUAN}

\section{Latar belakang}

Udang merupakan salah satu komoditas unggulan sektor perikanan setelah tuna, tongkol, cakalang. Negara pengimpor udang dari indonesia antara lain Jepang, Amerika Serikat, Malaysia dan Singapura. Udang diekspor dalam bentuk udang segar dan udang beku (Ashari et al. 2016). Salah satu permasalahan setelah udang keluar dari air adalah terjadinya diskolorisasi. Diskolorisasi atau melanosis adalah peristiwa atau pembentukan bintik hitam (blackspot) pada tubuh udang bagian kepala dan karapas. Pembentukan bintik hitam dapat menurunkan tingkat penerimaan konsumen sehingga dapat menurunkan nilai ekonominya, walaupun pigmen tersebut tidak bersifat berbahaya (Nirmal et al. 2015).

Peristiwa pembentukan blackspot terjadi karena adanya aktivitas enzim polifenol oksidase (PPO) yang mengoksidasi senyawa yang mengandung gugus fenolik seperti asam amino tirosin, membentuk quinon. Quinon adalah zat yang bersifat mudah bereaksi baik dengan asam amino lain atau dengan quinon itu sendiri, secara spontan membentuk polimer melanin yang berwarna hitam (Vavricka et al. 2010). Pembentukan bintik hitam tersebut akan berlangsung terus walaupun pada penyimpanan suhu chilling (Sriket et al. 2007). Pembentukan bintik hitam ini dapat dihambat pada suhu beku (Yen 2014).

Pencegahan pembentukan bintik hitam pada perusahaan-perusahaan eksportir udang segar, biasanya menggunakan bahan tambahan pangan yaitu sodium metabisulfit (SMS) (Uran dan Yilmaz 2015). Namun senyawa ini mempunyai katerbatasan penggunaan karena kelebihan residunya dapat mempengaruhi kesehatan (Pardio et al. 2011). Penelitian-penelitian dilakukan untuk mencari bahan pengganti sodium metabisulfit sperti menggunakan ekstrak bahan alam dari tanaman-tanaman yang diketahui mempunyai kemampuan 
antioksidan. Penelitian tersebut antara lain menggunakan ekstrak biji anggur (Sun et al. 2014), ekstrak kayu pohon nangka Artocarpus heterophyllous $(\mathrm{AH})$ (Nguyen et al. 2016) dan batang sereh (Xylocarpus granatum) (Kartikasari et al. 2017)

Bawang merah dan bawang putih digunakan sebagai bumbu pada masakan. Bawang merah mengandung senyawa bioaktif yang mempunyai kemampuan antioksidan, kaya akan senyawa fenolik dan flavonoid seperti quercetin, alluisida dan kamferol (Mohamed 2013). Bawang putih mengandung senyawa rutin (Trifunschi et al. 2015). Penelitian bertujuan untuk mengkaji penggunaan ekstrak bawang merah (Allium cepa L.) dan bawang putih (Allium sativum) sebagai penghambat pembentukan blackspot pada udang vaname pada berbagai konsentrasi ekstrak bawang.

\section{BAHAN DAN METODA}

\section{Bahan}

Bahan utama yang digunakan pada penelitian ini antara lain udang diperoleh dari BAPPL STP Serang, Jawa Barat. Bawang merah dan bawang putih didapatkan dari pasar di Bogor, Jawa Barat. Bahan kimia yang digunakan antara lain sodium metabisulfit, aquades, sodium metabisulfit. Peralatan yang digunakan antara lain chromameter CR-310, Minolta, Jepang, food processor, stereofoam

Preparasi udang dari tambak ke laboratorium (Nirmal and Benjakul 2011)

Udang vaname berukuran 55-60 ekor per kg diambil dari tambak BAPPL Serang, dalam keadaan hidup. Kemudian dimatikan secara cepat dengan cara disimpan dalam coolbox yang berisi es batu. Setelah mati, udang direndam dalam larutan bawang. Udang disimpan dalam stereofoam yang telah diberi es dengan perbandingan udang: es $=2: 1$. Suhu dalam stereofoam dijaga agar tetap 0-5 ${ }^{\circ} \mathrm{C}$ dengan cara mengganti es yang mencair dengan es yang baru secara periodik yaitu sehari sekali.

Pembuatan ekstrak bawang merah dan bawang putih (Yapi et al. 2015)

Bawang merah dan bawang putih diekstrak dengan tahapan meliputi persiapan bahan, pencucian, penghalusan, ekstraksi bawangbawangan dengan akuades dan penyaringan. Bahan bawang masingmasing dicuci, dan ditimbang sebanyak 1000 gr. Bawang ditambah dengan akuades dingin dengan perbandingan bawang : akuades sebesar 1:2 dan 1:1 dan kemudian dihaluskan menggunakan food processor. Supernatan dan filtrat dipisahkan menggunakan kertas saring. 
Larutan supernatan bawang digunakan untuk merendam udang selama 30 menit kemudian diamati perubahan pada udang selama 10 hari pada penyimpanan suhu $\quad 0 \quad{ }^{\circ} \mathrm{C}$ dalam stereofoam. Penggantian es yang mencair dengan es yang baru pada stereofoam dilakukan untuk menjaga suhu tepat sama sampai akhir penelitian, dilakukan setiap hari.

\section{Desain penelitian}

Desain penelitian ini disajikan pada Tabel 1 Rancangan percobaan menggunakan desain rancangan acak lengkap (RAL) dengan 3 ulangan dan 1 faktor yaitu perbedaan jenis ekstrak 2 level konsentrasi. Respon perlakuan yang diamati adalah nilai melanosis, warna $L^{*} a^{*} b^{*}$ dan kesegaran udang. Pengamatan dilakukan selama 12 hari pengamatan dimana pada setiap dua hari dilakukan pengamatan. Penentuan nilai melanosis dan kesegaran udang dilakukan oleh panelis tidak terlatih sebanyak 30 orang taruna Jurusan Penyuluhan Perikanan, Sekolah Tinggi Perikanan.

Tabel 1 Desain penelitian aplikasi bawang-bawangan pada udang vaname

\begin{tabular}{|c|c|c|c|}
\hline \multirow{2}{*}{ No } & \multirow{2}{*}{$\begin{array}{c}\text { Perlakuan } \\
\text { (Larutan Perendam Udang) }\end{array}$} & \multicolumn{2}{|c|}{$\begin{array}{c}\text { Konsentrasi } \\
\text { Bawang : Akuades }\end{array}$} \\
\hline & & $1: 1$ & $1: 2$ \\
\hline \multirow[t]{3}{*}{1} & Ekstrak bawang merah & A1.1 & A2.1 \\
\hline & & A1.2 & A2.2 \\
\hline & & A1.3 & A2.3 \\
\hline \multirow[t]{3}{*}{2} & Ekstrak Bawang Putih & A1.1 & B2.1 \\
\hline & & B1.2 & B2.2 \\
\hline & & B1.3 & B2.3 \\
\hline \multirow[t]{3}{*}{3} & Sodium metabisulfit (kontrol positif) konsentrasi $1.25 \%$ & C1.1 & \\
\hline & a 2013) & $\mathrm{C} 1.2$ & \\
\hline & & C1.3 & \\
\hline \multirow[t]{3}{*}{4} & Kontrol (kontrol negatif) & D1.1 & \\
\hline & & D1.2 & \\
\hline & & D1.3 & \\
\hline
\end{tabular}


Tabel 2 Score organoleptik tingkat pembentukan blackspot (nilai melanosis).

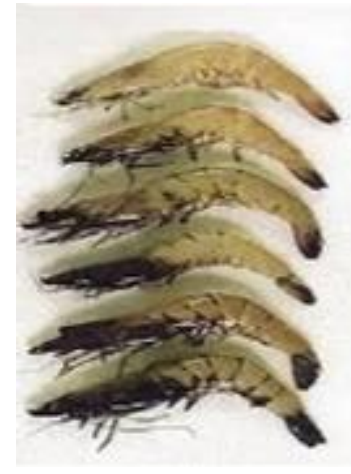

\begin{tabular}{l|l|}
\hline \multicolumn{1}{c|}{ Skala } & \multicolumn{1}{|c|}{ Deskripsi } \\
\hline 0 & Tanpa noda \\
\hline 2 & Sedikit, terdapat pada beberapa udang \\
\hline 4 & $\begin{array}{l}\text { Sedikit, terdapat pada sebagian besar } \\
\text { udang }\end{array}$ \\
\hline 6 & $\begin{array}{l}\text { Moderat, terdapat pada sebagian besar } \\
\text { udang }\end{array}$ \\
\hline 8 & $\begin{array}{l}\text { Banyak, terdapat pada sebagian besar } \\
\text { udang }\end{array}$ \\
\hline 10 & Banyak, tertolak \\
\hline
\end{tabular}

Sumber : Otwell dan Marshall (1996) di dalam Kim (2000)

Nilai melanosis (Montero et al. 2011)

Pembentukan blackspot diamati secara visual pada masing-masing sampel udang yang telah diinkubasi menggunakan ekstrak. Pengamatan dilakukan oleh 30 panelis semi terlatih menggunakan 1-10 nilai. Penentuan nilai 0 jika tidak ada pembentukan blackspot 2 jika sedikit (hingga 20\% permukaan udang terjadi blackspot) ; 4 jika pembentukan warna moderate (20\% sampai dengan $40 \%$ permukaan udang terjadi blackspot); 6 jika notable (40\% hingga $60 \%$ permukaan udang terdapat blackspot; 8 jika banyak sekali (60\% hingga $80 \%$ permukaan udang terdapat blackspot); 10 jika amat sangat banyak (80\% hingga $100 \%$ permukaan udang terdapat blackspot. Sampel udang diinkubasi hingga 10 hari pengamatan melanosis (blackspot). Nilai organoleptik pembentukan blackspot disajikan pada Tabel 1.

\section{Pengamatan kesegaran udang}

Uji kesegaran udang dilakukan sebagai salah satu faktor pembatas tingkat penerimaan konsumen terhadap udang yang disimpan dingin. Pengamatan kesegaran udang bertujuan sebagai kontrol terhadap kondisi kesegaran udang yang diberi ekstrak bawang bersamaan dengan pengamatan pembentukan blackspot. Standar pengamatan udang segar secara sensori menggunakan SNI Udang Segar No. 01- 2728.1-2006 meliputi atribut kenampakan, tekstur dan bau.

Pengukuran warna (Palou et al. 1999)

Penentuan komponen yaitu warna terang (ligthness) $L^{*}, \quad$ kemerahan (redness) $\mathrm{a}^{*}$, dan kekuniangan (yellowness) $b^{*}$ pada udang selama 10 hari pengamatan pada suhu $0{ }^{\circ} \mathrm{C}$, Jepang yang dikalibrasi dengan standar 
wana putih. Ketiga nilai warna menurut International Commission of Illumination, CIE (L, $\left.a^{*}, b^{*}\right)$ diukur dalam tiga kali pengukuran per sampel, dan pengukuran dilakukan pada udang secepatnya.

Indeks browning dapat dihitung dari: $\mathrm{BI}=[100(X-0,31)] / 0,172$

Dimana $X=(a+1,75 L) /(5,645 L+a-$ $3,012 b)$,

menyatakan warna coklat yang murni akibat aktivitas enzim PPO pada substrat.

\section{Analisis data}

Data yang ditampilkan adalah nilai rata-rata \pm standar deviasi dari tiga kali ulangan. Data dianalisa secara statistik dengan analysis of variance (ANOVA) satu arah (One way) dan batas kepercayaan 95\% $\quad(p<0,05)$ menggunakan software Statistical of Package for the Social Science (SPSS) versi 17.

\section{HASIL PENELITIAN}

Nilai melanosis

Hasil penelitian menunjukkan, nilai melanosis tertinggi yaitu 10 pada hari ke-10 dicapai oleh kontrol udang tanpa perlakuanekstrak bawang dan sodium metabisulfit (SMS). Nilai melanosis terendah dicapai oleh udang dengan perendaman SMS diikuti oleh udang dengan perendaman ekstrak bawang merah:aquades sebesar 1:1. Sedangkan nilai melanosis pada hari ke10 udang yang direndam menggunakan larutan bawang merah:akuades 1:2, bawang putih 1:2 dan bawang putih 1:1 tidak berbeda. Udang yang diberi ekstrak bawang, secara keseluruhan, masih mempunyai nilai melanosis yang lebih rendah dibandingkan dengan kontrol udang tanpa ekstrak, namun nilai melanosis udang dengan ekstrak bawang mempunyai nilai melanosis yang lebih tinggi daripada udang yang diberi SMS. Hal tersebut berarti melanosis udang dapat dihambat dengan ekstrak bawang, tetapi SMS masih lebih efektif menghambat melanosis.

Sodium metabisulfit (SMS) dapat lebih efektif menghambat pembentukan blackspot karena mencegah terjadinya polimerisasi senyawa quinon secara irreversibel membentuk komponen yang tidak berwarna (Montero et al. 2011). Selain menghambat melanosis, SMS juga dapat menghambat pertumbuhan bakteri seperti bakteri Salmonella typhimurium (Kusumaningrum dan Yanuardi 2012). Sodium metabisulfit $\left(\mathrm{Na}_{2} \mathrm{~S}_{2} \mathrm{O}_{5}\right)$ merupakan bahan tambahan pangan yang legal dengan kode E223 dengan batas maksimum penggunaan $150 \mathrm{mg} / \mathrm{kg}$ krustasea mencegah melanosis. Penggunaan SMS dibatasi karena konsumsi SMS dapat memicu 
alergi seperti asthma (Edmonds 2006). Penelitian Fossati et al. (2016) menyatakan bahwa alternatif pengganti SMS dapat digunakan garam $\mathrm{NaCl}$, yang tidak menimbulkan alergi namun berpengaruh terhadap flavor udang karena mempunyai rasa yang asin.

Penggunaan ekstrak tanaman untuk menghambat melanosis akan lebih efektif jika dikombinasi dengan perlakuan lain. Penggunaan ekstrak bahan alam seperti menggunakan ekstrak rosemary dan teh hijau (ekstraksi menggunakan etanol konsentrasi 2 $\mathrm{g} / 100 \mathrm{ml}$ ) yang dikombinasi dengan sodium metabisulfit $(1.25 \mathrm{~g} / 100 \mathrm{ml})$ lebih efektif menghambat melanosis dibandingkan ekstrak tanaman secara



Gambar 1. Nilai melanosis udang vaname yang direndam dalam ekstrak bawang merah, bawang putih dan sodium metabisulfit (SMS)

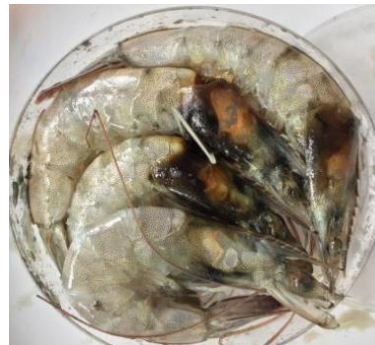

Ekstrak bawang merah 1:2

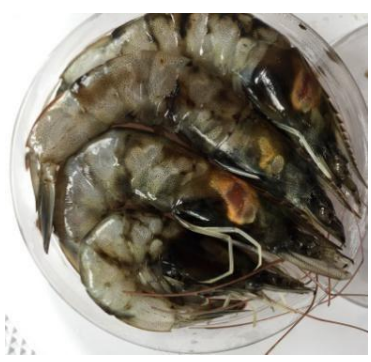

Bawang putih 1:1

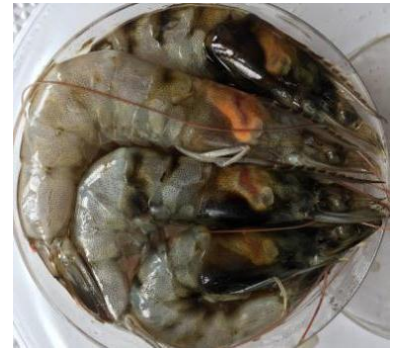

Ekstrak bawang merah 1:1

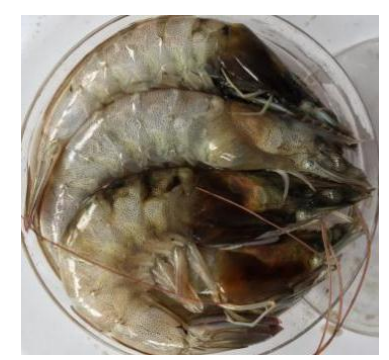

Sodium metabisulfit (SMS)

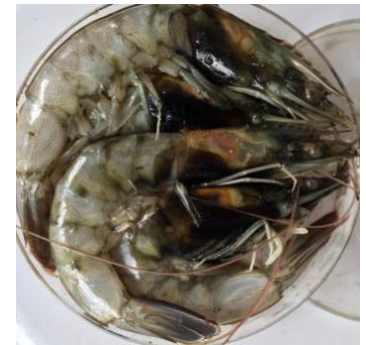

Ekstrak bawang putih 1:2

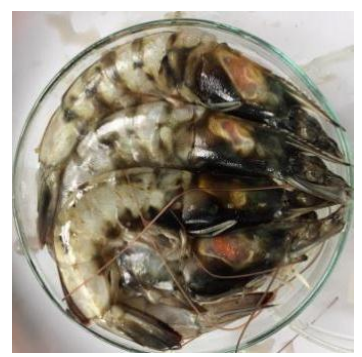

Kontrol

Gambar. 2 Udang vaname penyimpanan hari ke-10 pada suhu 0 oC setelah direndam pada berbagai ekstrak bawang dan SMS 
sendiri-sendiri. Kombinasi tersebut juga dapat mengurangi penggunaan SMS (Yatmaz dan Gokoglu 2016).

Kombinasi lain yang dapat dilakukan adalah dengan menggunakan beberapa ekstrak tanaman yang saling mendukung (sinergi) menghambat pembentukan blackspot tanpa menyebabkan perubahan mutu atribut lainnya seperti penggunaan ekstrak bawang dikombinasi dengan ektrak teh hijau (Haghparast et al. 2011). Grafik laju melanosis udang vannamei yang diberi ekstrak berbagai jenis bawang disajikan pada Gambar 1. Pembentukan blackspot pada udang vannamei yang diberi ekstrak berbagai jenis bawang dan sodium metabisulfit disajikan pada Gambar 2.

\section{Kesegaran udang}

Nilai kesegaran udang diuji secara organoleptik, meliputi pengamatan kenampakan, tekstur dan bau. Pada parameter kenampakan penyimpanan hari ke-10, terlihat bahwa udang dengan perendaman larutan bawang merah konsentrasi 1:2 (aquades: ekstrak bawang) dan perendaman SMS, mempunyai nilai kenampakan yang sama, dan paling tinggi yaitu sebesar $5 \pm 0,0$. Atribut kenampakan pada kesegaran udang berhubungan dengan pembentukan warna pada badan udang yang merupakan hasil reaksi biokimia seperti akibat oksidasi lipid pada udang mengakibatkan perubahan warna kekuningan dan pembentukan blackspot dan reaksi mikrobiologi. Reaksi enzimatik ini akan terus berlangsung walaupun udang disimpan pada suhu dingin $-15{ }^{\circ} \mathrm{C}$ hingga $-5{ }^{\circ} \mathrm{C}$ (Tsironi et al. 2009) dan pada jenis sotong cuttlefish penyimpanan suhu $0-37 \quad{ }^{\circ} \mathrm{C}$ (Thanonkaew et al. 2007).

Penyimpanan udang pada suhu dingin yaitu suhu $0{ }^{\circ} \mathrm{C}$ menyebabkan peranan mikroba belum dominan dimana peranan mikroba ini akan cepat terdeteksi dengan adanya bau yang menyengat. Namun penyimpanan dingin tidak dapat efektif menghambat kerja enzim endogeneus pada udang sehingga tetap diperlukan bahan tambahan menghambat pembentukan blackspot walaupun udang disimpan dingin (Rahimabadi et al. 2016). Tingkat kesegaran udang pada atribut tekstur pada hari ke-10 yang terbaik adalah udang dengan perendaman ekstrak bawang merah $1: 1$ dan SMS.

Mutu atribut bau tidak mengalami perubahan yang signifikan secara keselurusan perlakuan. Perubahan mutu bau tidak secepat perubahan mutu atribut kenampakan. Kemungkinan perubahan mutu atribut bau dapat dihambat dengan pendinginan, 


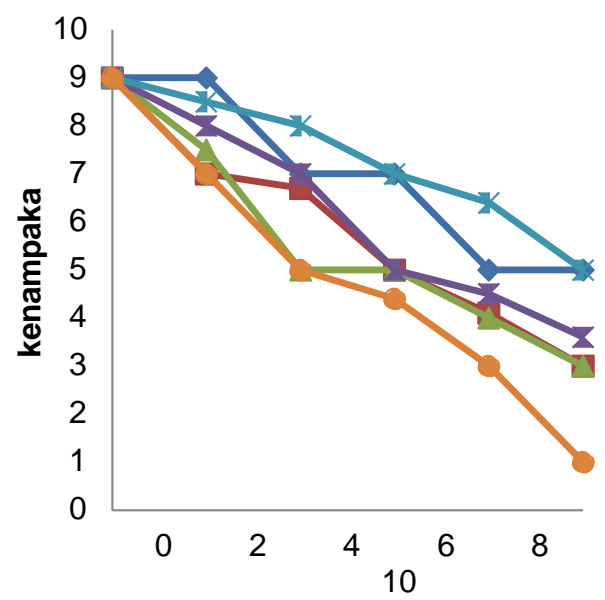

Hari ke-

a)

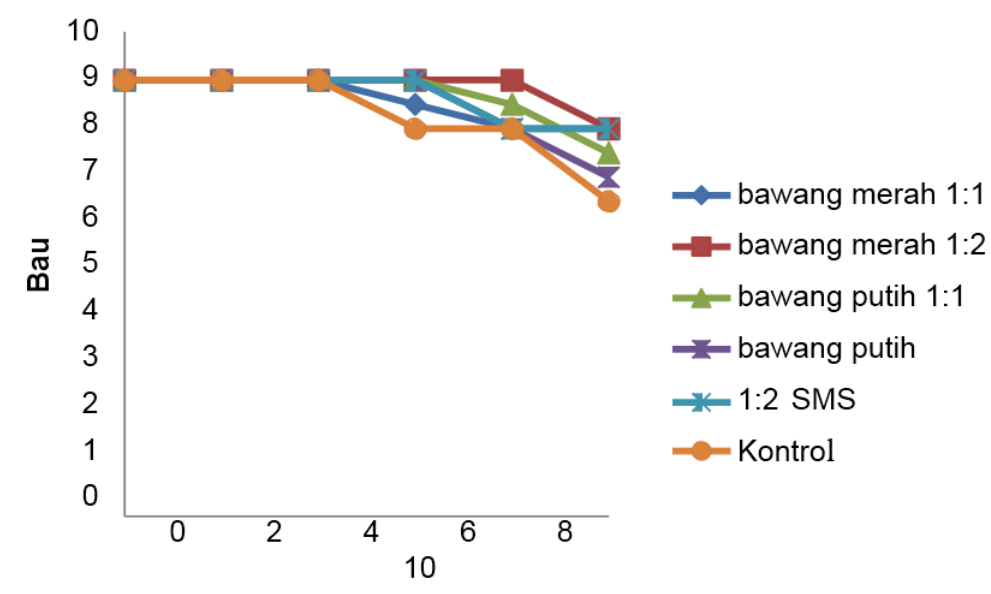

Hari ke-

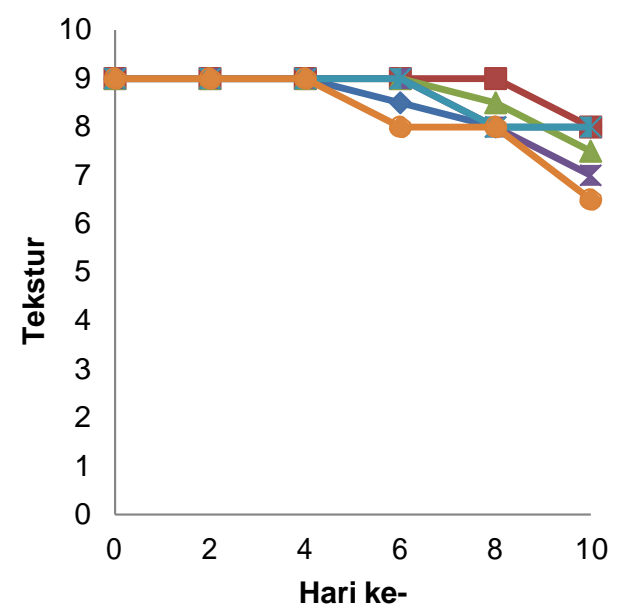

b)

c)

Gambar. 3 Tingkat kesegaran udang pada tiga atribut mutu organoleptik (a) Kenampakan; (b) Tekstur; (c) Bau, diberi perlakuan ekstrak dan SMS disimpan selam 10 hari pada suhu 0 oC

sehingga keberadaan ekstrak bawang dan SMS tidak berpengaruh secara signifikan. Perubahan mutu atribut bau pada produk ikan segar disebabkan terjadinya perubahan komponen kimia ikan seperti protein, lemak dan karbohidrat menjadi komponen yang lebih sederhana seperti basa- basa volatil (TVB) dan asam tio barbiturik
(TBA) mengakibatkan bau tengik dan bau susu (Chun et al. 2014). Perubahan mutu atribut bau yang tidak signifikan juga dapat diartikan bahwa tidak ada perubahan bau yang signifikan akibat perendaman udang dalam larutan ekstrak bawang dan SMS. Salah satu karakteristik pemanfaatan ekstrak bahan alam atau tanaman yang penting 


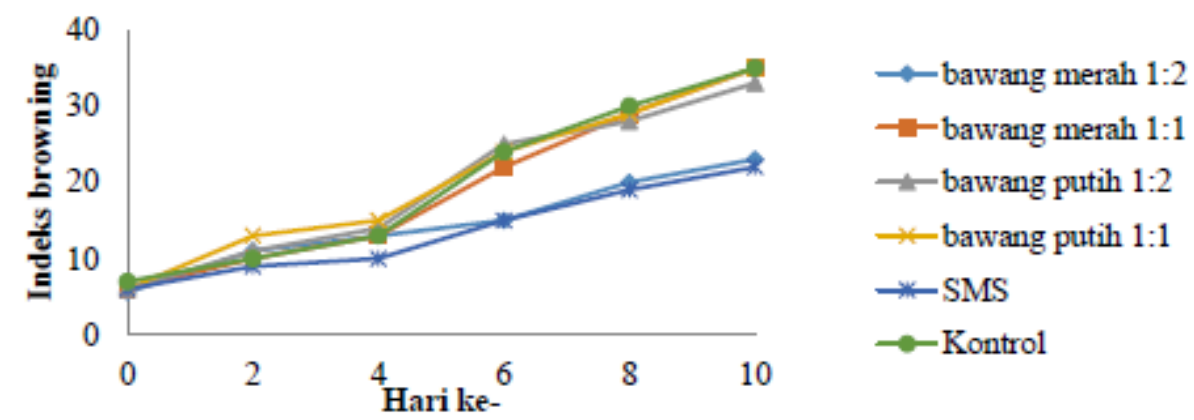

Gambar. 4 Indeks browning udang yang diberi perlakuan ekstrak bawang dan sodium metabisulfit (SMS) disimpan selama 10 hari pada suhu 0 oC

adalah tidak menimbulkan bau atau aroma baru pada produk yang diaplikasikannya (El- hanafy et al. 2011).

Perubahan mutu atribut tekstur selama penyimpanan $0^{\circ} \mathrm{C}$ selama 10 hari yang paling lambat adalah pada udang yang direndam menggunakan bawang merah 1:2. Namun secara keseluruhan tidak terjadi perbedaan mutu atribut tekstur yang signifikan. Perubahan mutu atribut tekstur akibat aktivitas enzimatik seperti enzim protease mengakibatkan softening, sehingga tektur produk perikanan menjadi lunak (Lougovois dan Kyrana 2005). Penelitian ini seperti penelitian aplikasi ekstrak tanaman, yaitu teh hijau pada filet ikan tidak menyebabkan terjadinya perubahan mutu atribut tekstur (Yerlikaya dan Gökoglu 2010).

Warna coklat dikuantifikasikan menggunakan tiga elemen warna $L, a^{*}$ dan $b^{*}$ yang merupakan hasil pengukuran menggunakan khromameter. Indeks pencoklatan
(Browning index $=B I$ ) merupakan hasil rumus menggunakan elemen warna tersebut (Palou et al. 1999). Nilai BI udang yang baik kontrol maupun udang direndam dalam ekstrak berbagai jenis bawang dan sodium metabisulfit tertinggi adalah udang tanpa perlakuan atau kontrol, dimana terjadi pembentukan warna cokelat yang tinggi. Perbedaan kenaikan nilai BI juga terjadi penambahan ekstrak bawang merah pada terong (Solanum melongena L.) (Barbagallo et al. 2012); perlakuan panas dan penambahan asam askorbat pada potongan buah apel (Malus domestica Borkh) (Javdani, Ghasemnezhad, dan Zare 2013)

Udang yang direndam dalam ekstrak bawang merah 1:1 mempunyai nilai $\mathrm{BI}$ yang terendah yaitu $22.00 \pm 0.94$, dibandingkan ekstrak bawang lainnya pada penyimpanan hari ke-10. Nilai ini tidak berbeda nyata dengan nilai indeks browning udang yang direndam pada SMS yaitu 23.00 \pm 1.2 . Laju kenaikan BI 
pada hari ke 0-4 secara umum berlangsung lambat, namun setelah itu berlangsung cepat. Hal ini dapat dijelaskan bahwa enzim PPO atau enzim tyrosinase mempunyai substrat Ltyrosin, dimana ini merupakan substrat monofenolik yang utama pada hewan. Tyrosin adalah monohidroksil phenol. Reaksi hidroksilasi tyrosin oleh enzim PPO membentuk dihidroksilphenilalanin (DOPA). Reaksi hidroksilasi monofenol ini berlangsung lambat dibandingkan reaksi oksidasi difenol menjadi quinon). Quinon adalah senyawa yang sangat reaktif, dan dapat membentuk polimer secara spontan menjadi komponen dengan berat molekul besar yaitu melanin, bereaksi dengan asam amino dan protein membentuk warna coklat (browning) (Kim et al. 2002). Nilai indeks browning pada penelitian ini disajikan pada Gambar 4.

\section{KESIMPULAN}

Udang dengan perendaman sodium metabisulfit mempunyai nilai melanosis yang paling rendah pada penyimpanan hari ke-10 suhu $0{ }^{\circ} \mathrm{C}$ dibandingkan udang dengan perendaman ekstrak bawang merah dengan perbandingan 1:1 dan 1:2 dan ekstrak bawang putih 1:1 dan 1:2. Walaupun nilai melanosis menurun drastis, namun tingkat kesegaran udang masih terjaga pada keseluruhan perendaman dan kontrol, namun pada atribut kenampakan sudah turun dengan cepat. Udang yang direndam menggunakan ekstrak bawang merah dan bawang putih, tidak menimbulkan bau dan tekstur yang berbeda dengan udang tanpa ekstrak. Udang dengan perendaman ekstrak bawang merah 1:1 dan perendaman dengan SMS mempunyai nilai indeks browning terendah. Ekstrak air bawang merah 1:1 berpotensi untuk dapat dimanfaatkan menghambat pementukan blackspot pada udang, namun memerlukan kombinasi perlakuan baik dengan sodium mebisulfit maupun dengan bahan alam lainnya.

\section{DAFTAR PUSTAKA}

Ashari U, Sahara, Hartoyo S. 2016. Daya Saing Udang Segar Dan Udang Beku Indonesia. J. Manaj. Agribisnis, 13(1):1-13. doi:10.17358/JMA.13.1.1.

Barbagallo RN, Riggi E, Avola G, Patanè C. 2012. Biopreservation of "Birgah" Eggplant from Polyphenol Oxidase Activity Assayed In Vitro with Onion ( Allium cepa L .) by-products. Chem. Eng. Trans. 27(1984):1-6.

Chun HN, Kim B, Shin HS. 2014. Evaluation of a freshness indicator for quality of fish products during 
storage. Food Sci. Biotechnol. 23(5):1719-1725.

doi:10.1007/s10068-014-0235-9.

Edmonds M. 2006. Sodium Metabisulphite Alternatives. In Seafish Technology Implementation, Seafish. pp. 1-51.

El-hanafy AEALY, Shawky HA, Ramadan MF. 2011. Preservation Of Oreochromis Niloticus Fish Using Frozen Green Tea Extract: Impact On Biochemical. J of Food Proc and Preserv doi:10.1111/j.17454549.2011.00513.x.

Fang $X$, Sun $H$, Huang $B$, Yuan $G$. 2013. Effect of pomegranate peel extract on the melanosis of Pacific white shrimp ( Litopenaeus vannamei ) during iced storage. J. Food, Agric. Environ. Vol.11 11(1):105-109.

Fossati AAN, Bergmann GP, Oliveira LA, Ribeiro, Junior DPS, Schneider TMC, Kindlein L. 2016. Effects of Different Additives on Colorimetry and Melanosis Prevention of Atlantic Seabob Shrimp (Xyphopenaeus kroyeri) Stored under Refrigeration. Int. J. Fish. Aquac. 8(8):74-80. doi:10.5897/IJFA2016.0564.

Haghparast S, Kashiri H, Alipour G, Shabanpour B. 2011. Evaluation of Green Tea ( Camellia sinenses ) Extract and Onion ( Allium cepa L .) Juice Effects on Lipid Degradation and Sensory Acceptance of Persian Sturgeon ( Acipenser persicus ) Fillets: A Comparative Study. J. Agric. Sci. Technol. 13855-868.

Javdani Z, Ghasemnezhad M, Zare S. 2013. A comparison of heat treatment and ascorbic acid on controlling enzymatic browning of fresh-cuts apple fruit. Int. J. Agric. Crop Sci. 5(3):186-193.

Kartikasari L, Nurhayati APD, Setiawan E, Hidayati D, Ashuri NM, Saadah NN, Muzaki FK, Desmawati I. 2017. Bioaktivitas ekstrak batang Xylocarpus granatum sebagai anti black spot alternatif pada Litopenaeus vannamei pasca panen. J. Trop. Biodivers. Biotechnol. 2(1):16. doi:10.22146/jtbb.16385.

Kim HR. 2000. Enzymatic Properties of Protease from the Hepatopancreas of Shrimp, Penaeus japonicus. Fish. Aquat. Sci.

Kim J, Marshall M, Wei C. 2002. Polyphenoloxydase. In Seafood Enzymes: Utilization Dan Influence on Postharvest Seafood Quality, N. Haard (Ed. by), Marcel Dekker Inc., New York, pp. 271-315. 
Kusumaningrum HD, Yanuardi A. 2012. Kuantifikasi Reduksi Salmonella Typhimurium pada Udang Segar selama Penyimpanan Dingin dengan Penambahan Natrium Metabisulfit ]. JTIP. 23 (2):193198.

doi:10.6066/jtip.2012.23.2.193.Has il.

Lougovois V, Kyrana V. 2005. Freshness Quality And Spoilage Of Chill-Stored Fish. Nova Science Publisher.

Mohamed GA. 2013. Alliuocide A: A New Antioxidant Flavonoid from Allium cepa L. Phytopharmacology 4(2):220- 227.

Montero P, Lopez-Caballero M, PerezMateos M. 2011. The Effect of Inhibitors and High Pressure Treatment to Prevent Melanosis and Microbial Growth on Chilled Prawns (Penaeus japonicus). J. Food Sci. 661201-1206.

Nguyen HX, Nguyen NT, Ha M, Nguyen K, Le TH, Do TN Van. 2016. Tyrosinase inhibitory activity of flavonoids from Artocarpus heterophyllous. Chem. Cent. J. 49. doi:10.1186/s13065-016- 01507.

Nirmal NP, Benjakul S. 2011. Inhibition of melanosis formation in Pacific white shrimp by the extract of lead
( Leucaena leucocephala) seed. Food Chem. 128(2):427-432. doi:10.1016/j.foodchem.2011.03.0 48.

Nirmal NP, Benjakul S, Ahmad M, Arfat YA, Panichayupakaranant P. 2015. Undesirable Enzymatic Browning in Crustaceans: Causative Effects and Its Inhibition by Phenolic Compounds. Crit. Rev. Food Sci. Nutr. 55(14):19922003.

doi:10.1080/10408398.2012.7551

48.

Palou E, Welti-chanes J, Palou E, Swanson 1999. Polyphenoloxidase Activity and Color of Blanched and High Hydrostatic Pressure Treated Banana Puree Polyphenoloxidase Activity and Color of Blanched and High Hydrostatic. J. Food Sci. . 64(1):42- 45. doi:10.1111/j.13652621.1999.tb09857.x.

Pardio VT, Waliszewski KN, Zun P. 2011. Original article Biochemical , microbiological and sensory changes in shrimp ( Panaeus aztecus ) dipped in different solutions using face-centred central composite design. Int. J. Food Sci. Technol. 46305-314. doi: $10.1111 / \mathrm{j} .1365-$ 2621.2010.02474 .x. 
Rahimabadi Z, Zarrin K, Zarei M, Gaffari M, Rahnama M. 2016. Effects of genistein on melanosis and microbial quality of Litopenaeus vannamei during ice storage. 15(1):436-445.

Roldan E, de Ancos B, Sancez-Moreno C, Cano MP. 2008. Characterisation of Onion (Allium cepa L .) by-products as Food Ingredients with Antioxidant and Antibrowning Properties. Food Chem. 108907-916. doi:10.1016/ j.foodchem.2007.11.058.

Sriket $\mathrm{P}$, Benjakul S, Visessanguan W, Kijroongrojana K. 2007. Comparativestudies on the effect of the freeze thawing process on the physicochemical properties and microstructures of black tiger shrimp (Penaeus monodon) and white shrimp (Penaeus vannamei) muscle. Food Chem. 104113-121. doi: 10.1016/j.foodchem.2006.10.0 39.

Sun H, Lv H, Yuan G, Fang X. 2014. Effect of Grape Seed Extracts on the Melanosis and Quality of Pacific White Shrimp (Litopenaeus vannamel) during Iced Storage. Food Sci. Technol. Res. 20(3):671-677. doi:10.3136/fstr.20.671.

Thanonkaew A, Benjakul S, Visessanguan W, Decker EA.
2007. Yellow discoloration of the liposome system of cuttlefish ( Sepia pharaonis ) as influenced by lipid oxidation. Food Chem. 102219-224.

doi:10.1016/j.foodchem.

2006.05.008.

Trifunschi S, Munteanu MF, Agotici V, Pintea S, Gligor R. 2015. Determination of Flavonoid and Polyphenol Compounds in Viscum album and Allium sativum Extracts. Int. Curr. Pharm. J. 4(5):382385.doi:10.3329/icpj.v4i5.22861.

Tsironi T, Dermesonlouoglou E, Giannakourou M, Taoukis P. 2009. Shelf life modelling of frozen shrimp at variable temperature conditions. LWT - Food Sci. Technol. 42(2):664-671. doi:10.1016/j.Iwt.2008.07.010.

Uran H, Yilmaz I. 2015. Determination of the total sodium metabisulphide level of shrimps ( Parapenaeus longirostris ) sold in Tekirdag. J. Environ. Res. Prot. Determ. 12(3):79-83.

Vavricka CJ, Christensen BM, Li J. 2010. Melanization in living organisms: A perspective of species evolution. Protein Cell 1(9):830-841. doi:10.1007/s13238-010-0109-8. 
Yapi JC, Gnangui SN, Dabonné S. 2015. Inhibitory Effect of Onions and Garlic Extract on the Enzymatic Browning of an Edible Yam ( Dioscorea cayenensisrotundata cv . Kponan ) cultivated in Côte d Ivoire. Int. J. Curr. Res. Acad. 3(1):219-231.

Yatmaz HA, Gokoglu N. 2016. Effects of Plant Extract-Sulphide Combinations on Melanosis Inhibition and Quality in Shrimp (Aristeus Antennatus). Int. J. Food Prop. 19(2):359-370. doi:10.1080/10942912.2015.1031 247.

Yen C. 2014. Microbiological , physical and sensory quality of marine shrimp ( Peneaus spp .) sold by vendors in Trinidad, West Indies. 21(4):1279- 1288.

Yerlikaya P, Gökoglu N. 2010. Effect of previous plant extract treatment on sensory and physical properties of frozen bonito ( Sarda sarda ) fillets. Turkish J. Fish. Aquat. Sci. 10341- 349. doi:10.4194/trjfas.2010.0306. 